\title{
GROWTH PERFORMANCE AND BIO-ECONOMICS OF GROWING PIGS FED DIETS CONTAINING SEPARATELY FERMENTED AND UNFERMENTED CASSAVA TUBER WASTES
}

\author{
Aro $\mathrm{SO}^{1}$, Agbede $\mathrm{JO}^{* 1}$, Aletor $\mathrm{VA}^{1}$ and $\mathrm{AA}$ Ashimi ${ }^{1}$
}

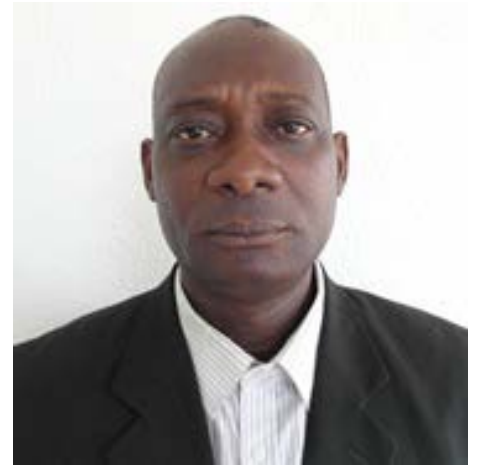

Oluwasola Agbede

${ }^{*}$ Corresponding author email: joagbede@yahoo.com

${ }^{1}$ Division of Nutritional Biochemistry, Department of Animal Production and Health, Federal University of Technology, P.M.B. 704, Akure, Nigeria 


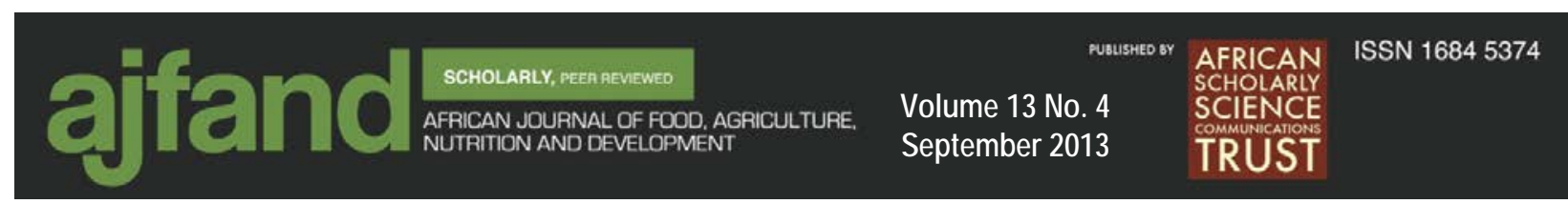

ABSTRACT

A feeding trial was conducted to investigate the performance, haematology, nutrient digestibility and economics of production of growing pigs fed diets containing differently fermented cassava starch residue (CSR) and cassava peels (CP) altogether referred to as cassava tuber wastes (CTW). The CSR and CP were each divided into three parts and processed as dry unfermented (UFCRS Diet 2; UFCP Diet 5), naturally fermented (NFCSR Diet 3; NFCP Diet 6) and microbial fermentation by inoculation (MFCSR Diet 4; MFCP Diet 7). Each part was included in a control diet (Diet 1) to replace maize at $20 \%$ dietary level to make a total of seven treatments. The final live weight (FLW), total live weight gain (TLG) and total feed consumption (TFC) of pigs fed the control diet were not significantly $(\mathrm{p}>0.05)$ different from those fed the test diets. However, the feed conversion ratio (FCR) of pigs fed the control was consistently lower (3.93) than those fed CSR (3.68-3.30) and CP (3.75-3.36)based diets. The response of RBC, WBC, $\mathrm{Hb}$ and PCV to the dietary treatment varied significantly $(\mathrm{p}<0.05)$ with the CTW-product incorporated into the diets vizs: RBC $10^{6} / \mathrm{mm}^{3}: 7.53$ vs CSR (5.71-6.26) and CP (4.71-5.75); WBC $10^{3} / \mathrm{mm}^{3}: 14.84$ vs CSR (9.06-10.06) and CP (8.53-10.90), and PCV\%: 36.75 vs CSR (35.75-36.00) and CP (32.5-37.00) while the MCHC and differential counts were not significantly ( $\mathrm{P}>0.05)$ affected. Varied effects on the digestibility of major ingredients in the diets were observed with the digestibility of dry matter (DM) been enhanced: $0.49-8.68 \%$ and 3.10-7.48\%, organic matter (OM): $1.60-9.37 \%$ and 3.41-8.43\%, crude protein: 3.336.17\% and $1.18-4.10 \%$, and crude fibre (CF): $24.37-30.52 \%$ and $2.34-28.80 \%$ by CSR and CP, respectively, over the control diet. The Mean Apparent Digestibility (MAD) for NFE (CSR 65.07\%; CP 69.33\%) was higher than that of the control diet (61.49\%). The cost of feed intake per pig decreased: $11.92-12.76 \%$ and $8.38-14.95 \%$, cost of feed per kg body weight gain: $14.84-22.66 \%$ and $14.84-21.88 \%$ with enhanced gross profit increase of $19.66-29.02 \%$ and $14.37-26.50 \%$ in CSR- and CP-based diets, respectively. It can, therefore, be concluded that CTW products could be included in pig's diet as an alternative to maize.

Key words: Bio-economics, cassava wastes, performance, pigs 


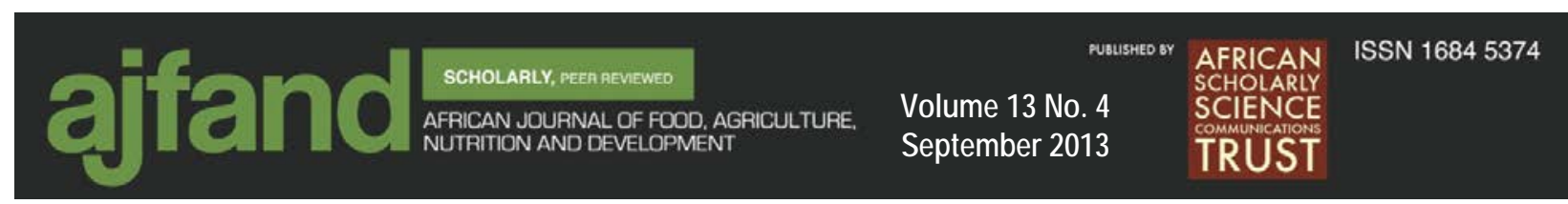

\section{INTRODUCTION}

The challenges of nature continue to spur man to make the best use of the available resources in his environment. This becomes more compelling as man is now faced with "food-feed" competition from livestock for the available grains and legumes [1]. Adequate nutrition is essential to the success of any livestock venture as feed cost alone accounts for more than $70 \%$ of the total cost of intensive non-ruminant animal production [2].

There has been a decline in livestock production in recent years in most of the lesser developed countries of the world. This is due to challenges of climate change on crop production, global economic melt-down and consequently increased cost of conventional raw materials for animal feed. Also, the conversion of the available conventional livestock ingredients to bio-fuels - a new vogue in our contemporary world to reduce cost on fossil fuels, has further pushed the cost of conventional feed ingredients beyond the reach of many livestock producers.

The use of non-conventional feed resources of agro-industrial origin has been researched by many authors and these have limitations of low protein value, high fibre content and low digestibility coupled with heavy loads of anti-nutritional factors [3, 4, $5,6]$. However, the quality of the non-conventional feed resources could be enhanced by fermentation and biotechnology applications $[7,8]$. The bioconversion and nutrient enrichment of the agro-industrial wastes through fermentation has not been exhaustively explored through animal experimentation especially in the solid substrate fermentation technique using a consortium of lactic acid bacteria and amylolytic fungi [8].

This study, therefore, investigated the effects of feeding two nutrient-enriched cassava tuber wastes on the growth indices, nutrient utilization, haematological indices and the economics of growing pigs in a twelve week feeding trial.

\section{MATERIALS AND METHODS}

\section{EXPERIMENTAL SITE}

The study was conducted in the Teaching and Research Farms of the School of Agriculture and Agricultural Technology, Federal University of Technology, Akure, Nigeria.

\section{CASSAVA WASTE COLLECTION AND FERMENTATION}

One hundred and fifty (150) kilogrammes, each of the fresh samples of cassava starch residues and cassava peels, were collected from Matna Foods Limited - a cassava starch and garri processing industry located on kilometer 19, Akure-Owo Express Road, Akure, Nigeria. The fresh samples of the cassava peels were immediately washed with distilled water. Thereafter, the two different samples were subdivided into three portions each and subjected to different processing techniques as follows:

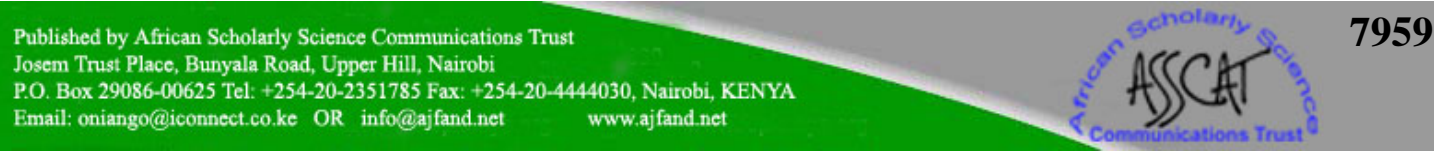




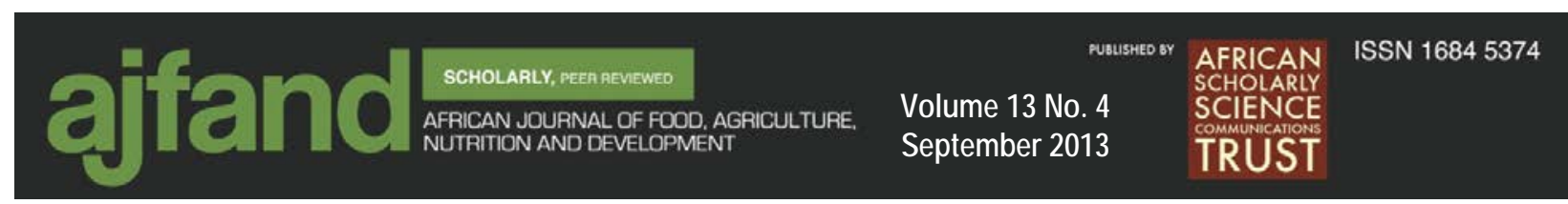

T1 = Fresh samples without any fermentation but was sun dried

T2 = Fresh samples were put in polythene bags, tied securely and left in a covered shed to ferment for 5 days (natural fermentation)

$\mathrm{T} 3$ = Sun dried samples were inoculated and fermented with Aspergillus fumigatus, Lactobacillus delbrueckii and Lactobacillus coryneformis (Micobially fermented).

The 'cassava tuber waste' (CTW) samples were fermented as previously described [8]. Prior to inoculation, each dried sample was heat-sterilized at $100^{\circ} \mathrm{C}$ for $30 \mathrm{~min}$ in water-tight cellophane bags. Inoculation was done at $37^{\circ} \mathrm{C}$ in cellophane-lined wooden trays measuring $60 \mathrm{~cm} \times 35 \mathrm{~cm} \times 4 \mathrm{~cm}$. The inoculated samples were then left for 5 days to ferment after which they were sun-dried and subsequently incorporated in the diets.

\section{EXPERIMENTAL DIETS}

Seven diets with the gross composition as presented in Table 1 were formulated and used for the trial. Diet 1 was the control and did not have CTW inclusion. Diets 2 - 4 had 20\% inclusion of unfermented cassava starch residues (UFCSR), naturally fermented cassava starch residues (NFCSR) and microbial fermented cassava starch residues (MFCSR), respectively. Diets 5 - 7 had 20\% inclusion of unfermented cassava peels (UFCP), naturally fermented cassava peels (NFCP) and microbial fermented cassava peels (MFCP), respectively. The control diet contained locally available feed ingredients that were commonly used for the formulation of commercial pig feeds in Nigeria, especially in the southwest (where Akure is located) and eastern Nigeria where pig enterprise had recently received boosts.

\section{EXPERIMENTAL DESIGN AND ANIMAL MANAGEMENT}

Two sets of experiments were conducted. In the first experiment, 28 weanling (Large white $\mathrm{x}$ Duroc crosses) pigs comprising 14 males and 14 females were used in a twelve week trial. The experimental design was a completely randomized arrangement in which four animals ( 2 males and 2 females) were randomly allotted to each of the seven treatments in which each animal served as a replicate of its treatment group. The animals were balanced for weight (mean weight: $12.01 \pm 0.3 \mathrm{~kg}$ ) and housed in individual pens with a dimension of $3 \mathrm{~m} \times 2 \mathrm{~m}$. Each pen had separate watering and feeding trough. The animals were fed their respective experimental diets for 12 weeks during which records for daily feed intake, weekly weight change, feed conversion ratio and feed efficiency were taken. The animals were fed at $5 \%$ of their body weight and provided water ad libitum throughout the duration of the experiment. During the last week of the experiment, blood samples were taken from the animals via the right saphenous vein with 19 gauge needles and emptied into EDTA (Ethelene Diamine Tetra-acetic Acid) coated bijou bottles for haematological analysis.

In the second experiment, 21 male pigs with an initial weight range between 12.7-14.4 $\mathrm{kg}$ were used in a digestibility trial that lasted 14 days. Male pigs were used in this

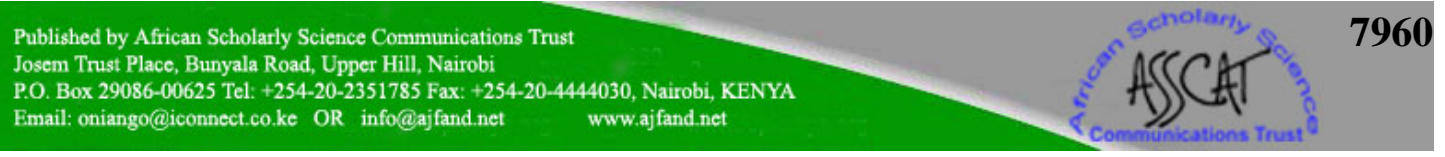




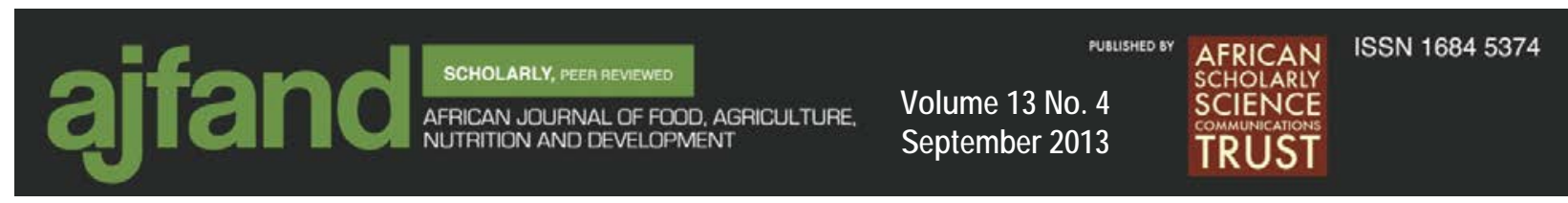

trial because of the ease of urine collection. The animals were allotted to the seven dietary treatments (Table 1). Each diet was fed to three animals kept in individual metabolic cages which have facilities for separate faecal and urine collection. The animals were fed at $5 \%$ of their body weight and had unrestricted access to drinking water. They were allowed seven days adjustment period and 7 days collection period adopted for feed intake, faecal and urine collection. The faeces and urine collected for the seven days were bulked and thoroughly mixed. About 200g of each of the faeces were freeze-dried and milled for analysis.

\section{BLOOD AND CHEMICAL ANALYSES}

The packed cell volume (PCV) was estimated by spinning about $50 \mu \mathrm{l}$ of each blood sample in heparinized capillary tubes in a haematocrit micro centrifuge for $5 \mathrm{~min}$ while the total red blood cell count (RBC) was determined using normal saline as the diluting fluid. The haemoglobin concentration $(\mathrm{Hb})$ was estimated using the cyanomethaemoglobin method by adding $20 \mu \mathrm{l}$ of the blood to $4 \mathrm{ml}$ of a diluting fluid (Drabkin's solution) and the colour density read off a colorimeter, while the mean corpuscular haemoglobin concentration (MCHC), the mean corpuscular volume (MCV) and mean corpuscular haemoglobin (MCH) were calculated as illustrated by Lamb [9]. Furthermore, the differential white blood counts were determined as described by Lamb [9]. The proximate compositions of the diets and faecal samples were determined according to AOAC [10].

\section{CALCULATIONS}

The feed conversion ratio was calculated as a ratio of feed intake to weight gain. The apparent digestibility of the nutrients was calculated using the formula:

Apparent digestibility of nutrient $=\underline{\text { Nutrient in the feed }- \text { nutrient in the faeces }} \times 100$ Nutrient in the feed [11]

The costs of feed ingredients (order than the cost of CTW) and pigs were calculated using the prevailing prices.

Data on the performance, haematological and digestibility parameters were subjected to one-way analysis of variance. Mean separation effected using the SPSS [12] Version 15 Statistical Package.

\section{RESULTS}

Table 2 shows that the final live weight (FLW), total live weight gain (TLG), total feed consumption (TFC) and daily live weight gain (DLG) of pigs fed the control diet were not significantly $(p>0.05)$ different from those fed the test diets. The feed conversion ratio (FCR) of pigs fed the control diet was however significantly $(p<0.05)$ lower (3.93) than those fed UFCSR, NFCSR, UFCP and MFCP-based diets (3.543.36) but were similar ( $>0.05$ ) to those fed MFCSR (3.68) and NFCP- (3.75) based diets. 


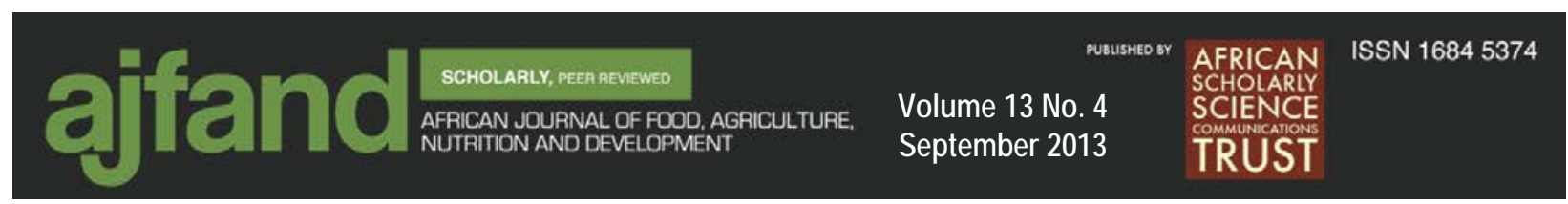

Table 3 shows that the red blood cell (RBC), white blood corpuscles (WBC), packed cell volume (PCV), haemoglobin concentration (Hb), mean corpuscular haemoglobin $(\mathrm{MCH})$ and mean corpuscular volume $(\mathrm{MCV})$ were significantly $(\mathrm{P}<0.05)$ affected by the dietary treatments. However, the MCHC and the differential counts were similar for all the treatment diets. The leucocyte counts were not significantly $(\mathrm{P}>0.05)$ affected by the dietary treatments. The neutrophils values ranged from $30.5-35.75 \%$ with mean of $33 \%$; lymphocytes: 53.5 - 58.75\% with a mean of $56 \%$; monocytes: $7.25-8.5 \%$ with a mean of $7.7 \%$ and eosinophils: $2.0-2.25$ with a mean of $2 \%$.

Table 4 shows that the apparent nutrient digestibility coefficients of all the nutrients measured were significantly $(\mathrm{P}<0.05)$ influenced by the dietary treatments. Pigs fed on the UFCSR-based diet had the highest (72.73\%) dry matter (DM) digestibility value while the lowest value of $66.42 \%$ was observed in pigs fed on the control diet. The organic matter (OM) digestibility followed the same trend as the DM digestibility. The pigs fed on MFCSR-based diet had the highest apparent crude protein digestibility (90.95\%) while the least value was recorded in pigs fed on the control diet.

The economics of production of pigs fed on the CTW-based diets and the control diet is presented in Table 5. The cost of feed per tonne ranged from $\$ 290.00$ for the MFCP diet to $\$ 330.47$ for the control diet. All the CTW-based diets with respect to the cost of feed per tonne, cost of feed consumed per pig and cost of feed per kg body weight gain were relatively cheaper than the control diet. The money's worth (final live weight $\mathrm{x}$ selling price/kg live weight) per pig was highest (\$70.82) in NFCSR-based diet and lowest (\$67.03) in the control group.

\section{DISCUSSION}

The need to source for economically viable feed resources that can lead to better animal protein production and consumption in the tropical countries has received more research attention of recent. Thus, the ability to use agricultural wastes, such as cassava processing wastes subjected to appropriate but farmers' friendly processing techniques will further expand and improve their use in animal feeding. In this present study, the inclusion of CTW-products in the diets led to comparable FLW, TLG and TFC of pigs with those on control diet. The numerical gain in weight that range 6.22$12.11 \%$ in TLG of pigs fed the CTW-products-based diets with attendant lower TFC over those fed the control diet is of great interest as this could not be statistically explained. Perhaps a longer experimental duration would elucidate a clear effect of the treatment on the pigs. However, the result indicated a beneficial effect of solid state fermentation technique adopted in this study and its improvement on the nutrient composition of the CTW-products used. The nutritional potentials of the CTWproducts could be efficiently tapped to revolutionize the livestock industry especially in developing countries where scarcity of the conventional feed ingredients is a perennial problem. These encouraging performance indicators would therefore lend credence to the opinion shared by Sucharita et al. [13] that research efforts in

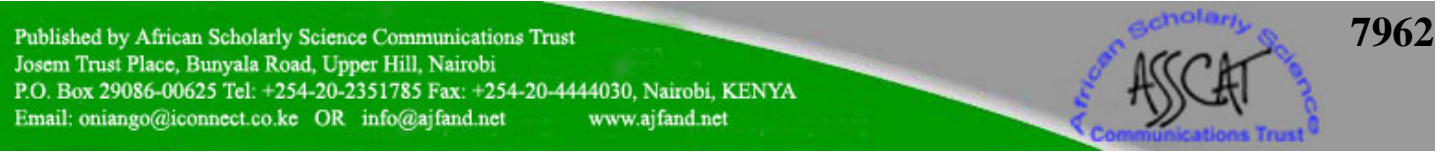




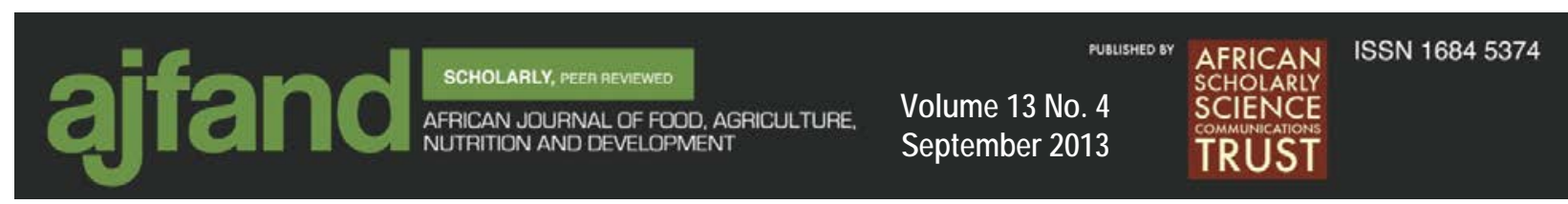

developing countries should be directed towards the use of non-conventional agricultural by-products.

With the exception of NFCP-based diet, all the mean RBC values obtained are within the normal range of $5 \times 10^{6} / \mathrm{mm}^{3}-8 \times 10^{6} / \mathrm{mm}^{3}$ while only the WBC of the pigs fed on the control diet fell within the range of $11.0-22.010^{3} / \mathrm{mm}^{3}$ [11]. Also, the $\mathrm{Hb}$ concentration and PCV fell within the normal range of 10-16g/dl (average value of $13 \mathrm{~g} / \mathrm{dl}$ ) and $32-50 \%$ (average of $42.0 \%$ ), respectively, for pigs [14]. This suggests that the inclusion of CTW in the diets may not have compromised the health status of the pigs. The MCHC values observed were similar for all the treatment diets. The study also shows that the values of the mean corpuscular haemoglobin $(\mathrm{MCH})$ and mean corpuscular volume (MCV) of pigs fed on the CTW-based diets were higher than those of pigs fed on the control diet. The values of MCV revealed that the animals that ate the CTW-based diets had larger red cell volumes and this was clearly enhanced in pigs fed cassava peels than those on cassava starch residues. The physiological adjustment to obviate the possible effects of residual cyanide toxicity by the animals might be responsible for this finding $[8,15,16]$.

The results of the apparent digestibility trial suggest that the CSR and CP products used in this study have variable effects on the digestibility of major ingredients in the diets. For instance, the dry matter (DM) digestibility was enhanced by $8.68 \%, 7.53 \%$ and $0.49 \%$ in UFCSR, NFCSR and MFCSR-based diets, and 7.48\%, 3.10\% and 5.93\% in UFCP, NFCP and MFCP-based diets over the control diet, respectively. Also, $9.37 \%, 8.33 \%$ and $1.62 \%$ improvement of organic matter (OM) digestibility in pigs fed UFCSR, NFCSR and MFCSR-based diets and $8.43 \%, 3.41 \%$ and $6.67 \%$ in pigs fed UFCP, NFCP and MFCP-based diets were observed over those fed the control diet, respectively. Similarly, improvement of 3.33\%, 4.39\%, 6.17\%, 1.18\%, $1.76 \%$ and $6.67 \%$ in crude protein digestibility in pigs fed UFCSR, NFCSR, MFCSR, UFCP, NFCP and MFCP-based diets were observed over those fed the control diet while crude fibre (CF) digestibility improved by 30.52\%, 27.68\%, 24.37\%, 28.80\%, 9.93 and $2.34 \%$, respectively. This tends to lend credence to why pigs fed on CTWbased diets had numerically enhanced performance than those fed on the control diet in terms of FLW and TLG, and significantly better FCR in most cases. This observed finding could be suggestive of the changes in the nutrient composition of the CTW products as a result of fermentation [17]. Also, higher Mean Apparent Digestibility (MAD) of NFE: $65.07 \%$ and $69.33 \%$ over $61.49 \%$ for the control diet were observed for pigs fed on the CSR- and CP-based diets, respectively. In general, better digestibility values were observed for DM, OM, CP and CF in the CSR-based diets than in CP-based diets, indicating that the solid state fermentation techniques adopted have more potential to improve the nutrient bio-availability in the CSR products than in the CP products. With exception of UFCSR, a decrease in ether extract digestibility was observed in the test diets compared with the control diet suggesting the possible inhibitory role of crude fibre in the diet on fat absorption due to a reduction in lipase activity while the digestibility variations of the cassava products could be as a result

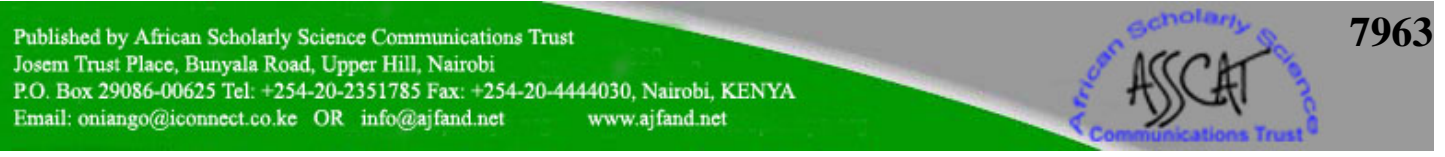




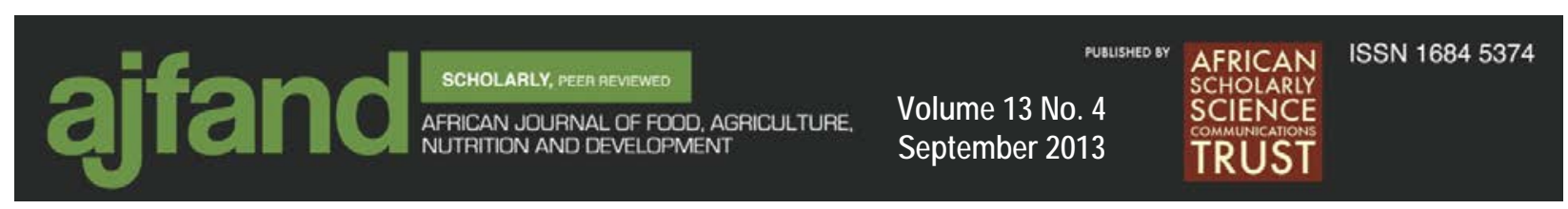

of their different rate of viscosity as occasioned by the extent and nature of fermentation $[18,19]$.

Furthermore, in this study the cost of feed intake per pig decreased, respectively, by $12.53 \%, 11.92 \%, 12.76 \%, 14.95 \% 14.95 \%$ and $8.38 \%$ in pigs fed UFCSR, NFCSR, MFCSR, UFCP, NFCP and MFCP-based diets relative to those fed the control diet. In addition, the gross profit increased considerably by $23.06 \%, 29.02 \%, 19.66 \%$, $21.45 \%, 14.37 \%$ and $26.50 \%$ in pigs fed UFCSR, NFCSR, MFCSR, UFCP, NFCP and MFCP-based diets, respectively. This suggests that it would be profitable to feed the CTW-products under study at $20 \%$ inclusion in pig's diet. This is, however, in agreement with the suggestion that the use of alternative feed resources could lead to profitable non-ruminant production in developing countries [6].

\section{CONCLUSION}

The study showed that the final live weight, total live weight gain and total feed consumption of pigs fed on the CTW-based diets were improved by solid state fermentation. This study also showed that the inclusion of CTW did not compromise the health status of the pigs. Solid state fermentation had varied effects on the digestibility and nutrient bio-availability but the digestibility of DM, OM, CP and CF were improved in the CTW-based diets than in the control diet. The economics of production showed that cost of production decreased with enhanced gross profit in the CTW-based diets and in the mean, the 20\% inclusion of CTW-products in pig diet could lead to reduction in the cost of pig production in the tropical countries. 
Table 1: Composition of the experimental diets (\%)

\begin{tabular}{llllllll}
\hline Ingredients & Diet 1 & Diet 2 & Diet 3 & Diet 4 & Diet 5 & Diet 6 & Diet 7 \\
\hline Maize & 40.00 & 28.00 & 28.00 & 28.00 & 28.00 & 28.00 & 28.00 \\
Groundnut cake & 23.43 & 28.43 & 25.82 & 24.66 & 25.95 & 22.16 & 21.32 \\
Palm kernel cake & 16.57 & 20.57 & 23.18 & 24.34 & 23.05 & 26.84 & 27.68 \\
Rice bran & 17.00 & - & - & - & - & - & - \\
UFCSR & - & 20.00 & - & - & - & - & - \\
NFCSR & - & - & 20.00 & - & - & - & - \\
MFCSR & - & - & - & 20.00 & - & - & - \\
UFCP & - & - & - & - & 20.00 & - & - \\
NFCP & - & - & - & - & - & 20.00 & - \\
MFCP & - & - & - & - & - & - & 20.00 \\
Bone meal & 1.50 & 1.50 & 1.50 & 1.50 & 1.50 & 1.50 & 1.50 \\
Oyster shell & 0.50 & 0.50 & 0.50 & 0.50 & 0.50 & 0.50 & 0.50 \\
Vit/min. premix & 0.50 & 0.50 & 0.50 & 0.50 & 0.50 & 0.50 & 0.50 \\
Salt & 0.50 & 0.50 & 0.50 & 0.50 & 0.50 & 0.50 & 0.50 \\
Total & 100.00 & 100.00 & 100.00 & 100.00 & 100.00 & 100.00 & 100.00 \\
Calculated & & & & & & & \\
Crude Protein (\%) & 20.10 & 20.20 & 20.29 & 20.26 & 20.11 & 20.02 & 20.06 \\
Crude fibre (\%) & 6.23 & 7.61 & 7.65 & 7.62 & 6.98 & 7.43 & 6.76 \\
ME (Kcal / kg) & 2927.7 & 2823.2 & 2844.8 & 2847.1 & 2871.3 & 2851.1 & 2854.4 \\
Analyzed & & & & & & & \\
Crude Protein (\%) & 20.3 & 20.3 & 20.2 & 19.5 & 20.1 & 20.1 & 20.1 \\
Crude fibre (\%) & 7.7 & 9.9 & 11.9 & 11.9 & 16.7 & 10.4 & 8.6 \\
\hline
\end{tabular}

UFCSR = Unfermented cassava starch residues, NFCSR = Naturally fermented cassava starch residues, MFCSR = Microbial fermented cassava starch residues, UFCP $=$ Unfermented cassava peel, NFCP $=$ Naturally fermented cassava peel and MFCP $=$ Microbial fermented cassava peel 
Table 2: Performance parameters of pigs fed conventional and cassava tuber waste-based diets

\begin{tabular}{|c|c|c|c|c|c|c|c|c|}
\hline Parameters & Control & UFCSR & NFCSR & MFCSR & UFCP & NFCP & MFCP & \pm SEM \\
\hline $\begin{array}{l}\text { Initial live } \\
\text { weight (kg) }\end{array}$ & 11.68 & 12.18 & 12.15 & 12.38 & 11.60 & 11.85 & 12.23 & 0.46 \\
\hline $\begin{array}{l}\text { Final live } \\
\text { weight (kg/pig) }\end{array}$ & 28.73 & 30.35 & 31.55 & 29.63 & 29.85 & 28.75 & 31.37 & 1.24 \\
\hline $\begin{array}{l}\text { Total live } \\
\text { weight gain } \\
\text { (kg/pig) }\end{array}$ & 17.05 & 18.18 & 19.40 & 17.25 & 18.25 & 16.90 & 19.15 & 0.81 \\
\hline $\begin{array}{l}\text { Total Feed } \\
\text { Consumed } \\
\text { (kg/pig) }\end{array}$ & 65.99 & 62.51 & 63.76 & 63.50 & 61.54 & 62.71 & 67.86 & 2.66 \\
\hline $\begin{array}{l}\text { Daily live } \\
\text { weight gain } \\
\text { (g/d/pig) }\end{array}$ & 0.20 & 0.21 & 0.23 & 0.21 & 0.22 & 0.20 & 0.23 & 0.01 \\
\hline FCR & $3.93^{\mathrm{a}}$ & $3.45^{\mathrm{bcd}}$ & $3.30^{\mathrm{d}}$ & $3.68^{\mathrm{abc}}$ & $3.36^{\mathrm{cd}}$ & $3.75^{\mathrm{ab}}$ & $3.54^{\mathrm{bcd}}$ & 0.06 \\
\hline
\end{tabular}

${ }^{\mathrm{a}-\mathrm{d}}=$ Means in the same row with different superscripts are statistically $(\mathrm{P}<0.05)$ different.

UFCSR $=$ Unfermented cassava starch residues, NFCSR $=$ Naturally fermented cassava starch residues, MFCSR $=$ Microbially fermented cassava starch residues, UFCP $=$ Unfermented cassava peels, NFCP = Naturally fermented cassava peels, MFCP $=$ microbially fermented cassava peels 
Table 3: Haematology of pigs fed conventional and Cassava tuber waste-based diets

\begin{tabular}{lcccccccr}
\hline Parameters & Control & UFCSR & NFCSR & MFCSR & UFCP & NFCP & MFCP & \pm SEM \\
\hline RBC $\left(10^{6} / \mathrm{mm}^{3}\right)$ & $7.53^{\mathrm{a}}$ & $6.26^{\mathrm{a}}$ & $6.07^{\mathrm{b}}$ & $5.71^{\mathrm{bc}}$ & $5.75^{\mathrm{bc}}$ & $4.71^{\mathrm{c}}$ & $5.48^{\mathrm{bc}}$ & 0.36 \\
\hline $\mathrm{WBC}^{3}\left(10^{3} / \mathrm{mm}^{3}\right.$ & $14.83^{\mathrm{a}}$ & $10.06^{\mathrm{b}}$ & $9.56^{\mathrm{b}}$ & $9.06^{\mathrm{b}}$ & $8.53^{\mathrm{b}}$ & $10.90^{\mathrm{ab}}$ & $9.69^{\mathrm{b}}$ & 1.41 \\
\hline $\mathrm{Hb}(\mathrm{g} / \mathrm{dl})$ & $12.25^{\mathrm{a}}$ & $12.03^{\mathrm{ab}}$ & $11.90^{\mathrm{ab}}$ & $11.90^{\mathrm{ab}}$ & $13.33^{\mathrm{a}}$ & $10.83^{\mathrm{b}}$ & $11.35^{\mathrm{ab}}$ & 0.50 \\
\hline PCV $(\%)$ & $36.75^{\mathrm{ab}}$ & $36.00^{\mathrm{ab}}$ & $35.75^{\mathrm{ab}}$ & $35.75^{\mathrm{ab}}$ & $37.00^{\mathrm{a}}$ & $32.50^{\mathrm{b}}$ & $34.00^{\mathrm{ab}}$ & 1.92 \\
\hline MCHC (\%) & 33.34 & 33.42 & 33.29 & 33.29 & 33.31 & 33.31 & 33.38 & 0.06 \\
\hline MCH $(\mathrm{pg})$ & $16.27^{\mathrm{b}}$ & $19.25^{\mathrm{ab}}$ & $20.89^{\mathrm{a}}$ & $20.89^{\mathrm{a}}$ & $23.16^{\mathrm{a}}$ & $23.20^{\mathrm{a}}$ & $22.65^{\mathrm{a}}$ & 1.13 \\
\hline MCV $\left(\mu \mathrm{m}^{3}\right)$ & $48.79^{\mathrm{b}}$ & $57.62^{\mathrm{ab}}$ & $62.75^{\mathrm{a}}$ & $62.75^{\mathrm{a}}$ & $69.51^{\mathrm{a}}$ & $69.66^{\mathrm{a}}$ & $67.80^{\mathrm{a}}$ & 2.08 \\
\hline $\begin{array}{l}\text { Differetial } \\
\text { counts (\%) }\end{array}$ & & & & & & & & \\
\hline Neutrophils & 33.50 & 30.50 & 32.00 & 33.00 & 32.50 & 35.75 & 34.00 & 2.75 \\
\hline Lymphocytes & 56.25 & 58.75 & 56.50 & 56.25 & 57.00 & 53.50 & 55.00 & 2.87 \\
\hline Monocytes & 7.25 & 7.75 & 8.50 & 7.50 & 7.50 & 7.75 & 8.00 & 0.85 \\
\hline Eosinophils & 2.00 & 2.00 & 2.00 & 2.25 & 2.00 & 2.00 & 2.00 & 0.00 \\
\hline Basophils & 1.00 & 1.00 & 1.00 & 1.00 & 1.00 & 1.00 & 1.00 & 0.00 \\
\hline
\end{tabular}

${ }^{\mathrm{a}, \mathrm{b}}=$ Means in the same row with different superscripts are statistically $(\mathrm{P}<0.05)$ different.

UFCSR $=$ Unfermented cassava starch residues, NFCSR = Naturally fermented cassava starch residues, MFCSR = Microbially fermented cassava starch residues, UFCP = Unfermented cassava peels, NFCP = Naturally fermented cassava peels, MFCP = microbially fermented cassava peels 
Table 4: Apparent nutrient digestibility of pigs fed conventional and cassava tuber waste-based diets

\begin{tabular}{lllllllll}
\hline Parameters (\%) & Control & UFCSR & NFCSR & MFCSR & UFCP & NFCP & MFCP & \pm SEM \\
\hline Dry matter dig. & $66.42^{\mathrm{b}}$ & $72.73^{\mathrm{a}}$ & $71.83^{\mathrm{ab}}$ & $66.75^{\mathrm{b}}$ & $71.79^{\mathrm{ab}}$ & $68.55^{\mathrm{ab}}$ & $70.61^{\mathrm{ab}}$ & 1.52 \\
\hline $\begin{array}{l}\text { Organic matter } \\
\text { dig. }\end{array}$ & $65.95^{\mathrm{b}}$ & $72.77^{\mathrm{a}}$ & $71.94^{\mathrm{a}}$ & $67.02^{\mathrm{ab}}$ & $72.02^{\mathrm{a}}$ & $68.25^{\mathrm{ab}}$ & $70.66^{\mathrm{ab}}$ & 1.54 \\
\hline $\begin{array}{l}\text { Crude protein } \\
\text { dig. }\end{array}$ & $85.34^{\mathrm{b}}$ & $88.28^{\mathrm{ab}}$ & $89.26^{\mathrm{ab}}$ & $90.95^{\mathrm{a}}$ & $86.36^{\mathrm{b}}$ & $86.87^{\mathrm{b}}$ & $88.99^{\mathrm{ab}}$ & 1.06 \\
\hline Crude fibre dig. & $49.32^{\mathrm{b}}$ & $70.98^{\mathrm{a}}$ & $68.20^{\mathrm{a}}$ & $65.21^{\mathrm{a}}$ & $69.27^{\mathrm{a}}$ & $54.76^{\mathrm{b}}$ & $50.50^{\mathrm{b}}$ & 1.75 \\
\hline $\begin{array}{l}\text { Ether extracts } \\
\text { dig. }\end{array}$ & $64.58^{\mathrm{ab}}$ & $73.13^{\mathrm{a}}$ & $59.57^{\mathrm{bc}}$ & $56.81^{\mathrm{bc}}$ & $50.72^{\mathrm{c}}$ & $35.54^{\mathrm{d}}$ & $2599^{\mathrm{d}}$ & 2.95 \\
\hline Ash dig. & $70.70^{\mathrm{a}}$ & $72.14^{\mathrm{a}}$ & $70.92^{\mathrm{a}}$ & $63.74^{\mathrm{b}}$ & $68.98^{\mathrm{a}}$ & $70.52^{\mathrm{a}}$ & $69.92^{\mathrm{a}}$ & 1.54 \\
\hline NFE dig. & $61.49^{\mathrm{bc}}$ & $67.18^{\mathrm{abc}}$ & $67.86^{\mathrm{ab}}$ & $60.17^{\mathrm{c}}$ & $70.24^{\mathrm{a}}$ & $66.94^{\mathrm{abc}}$ & $70.81^{\mathrm{a}}$ & 2.04
\end{tabular}

a,b,c,d $=$ Means in the same row but with different superscripts are statistically $(\mathbf{P}<0.05)$ significant.

UFCSR $=$ Unfermented cassava starch residues, NFCSR = Naturally fermented cassava starch residues, MFCSR $=$ Microbially fermented cassava starch residues, UFCP $=$ Unfermented cassava peels, NFCP = Naturally fermented cassava peels, MFCP = microbially fermented cassava peels. Dig. = Digestibility 
Table 5: Economic analysis of pigs fed conventional and Cassava tuber wastebased diets

\begin{tabular}{|c|c|c|c|c|c|c|c|c|}
\hline Parameters & Control & UFCSR & NFCSR & MFCSR & UFCP & NFCP & MFCP & SEM \\
\hline $\begin{array}{l}\text { Initial Live } \\
\text { weight/pig(kg) }\end{array}$ & 11.68 & 12.18 & 12.15 & 12.38 & 11.60 & 11.85 & 12.23 & 0.16 \\
\hline $\begin{array}{l}\text { Final live } \\
\text { weight/pig(kg) }\end{array}$ & 28.73 & 30.35 & 31.55 & 29.63 & 29.85 & 28.75 & 31.38 & 0.19 \\
\hline $\begin{array}{l}\text { Total Live weight } \\
\text { gain/pig(kg) }\end{array}$ & 17.05 & 18.18 & 19.40 & 17.25 & 18.25 & 16.90 & 19.15 & 0.24 \\
\hline $\begin{array}{l}\text { Total Feed } \\
\text { consumed/pig(kg) }\end{array}$ & 65.99 & 62.51 & 63.76 & 63.50 & 61.55 & 62.71 & 67.86 & 0.19 \\
\hline $\begin{array}{l}\text { Cost of weaner } \\
\operatorname{pigs}(\$)\end{array}$ & 81.14 & 81.14 & 81.14 & 81.14 & 81.14 & 81.14 & 81.14 & 0.00 \\
\hline $\begin{array}{l}\text { Cost of feed/tonne } \\
\text { (\$) }\end{array}$ & 330.47 & 300.33 & 296.60 & 294.93 & 296.73 & 291.27 & 290.00 & 0.21 \\
\hline $\begin{array}{l}\text { Cost of feed } \\
\text { intake/pig (\$) }\end{array}$ & 21.47 & 18.78 & 18.91 & 18.73 & 18.26 & 18.26 & 19.67 & 0.24 \\
\hline $\begin{array}{l}\text { Cost of feed/kg } \\
\text { body wt gain (\$) }\end{array}$ & $1.28^{\mathrm{a}}$ & $1.04^{\mathrm{b}}$ & $0.99^{\mathrm{b}}$ & $1.09^{\mathrm{b}}$ & $1.00^{\mathrm{b}}$ & $1.09^{\mathrm{b}}$ & $1.03^{\mathrm{b}}$ & 0.30 \\
\hline $\begin{array}{l}\text { Grower’s sales at } \\
\$ 2.33 / \mathrm{kg} \text { body wt. }\end{array}$ & 67.03 & 70.82 & 73.62 & 69.09 & 69.65 & 67.08 & 73.21 & 0.19 \\
\hline Gross profit (\$) & 24.43 & 31.75 & 34.42 & 30.41 & 31.10 & 28.53 & 33.24 & 0.33 \\
\hline
\end{tabular}

${ }^{a . b}=$ Means in the same row but with different superscripts are statistically significant $(\mathrm{P}<0.05)$

UFCSR $=$ Unfermented cassava starch residues, NFCSR $=$ Naturally fermented cassava starch residues, MFCSR = Microbially fermented cassava starch residues, UFCP = Unfermented cassava peels, NFCP = Naturally fermented cassava peels, MFCP = microbially fermented cassava peels 150 to US \$ as at March 2010 


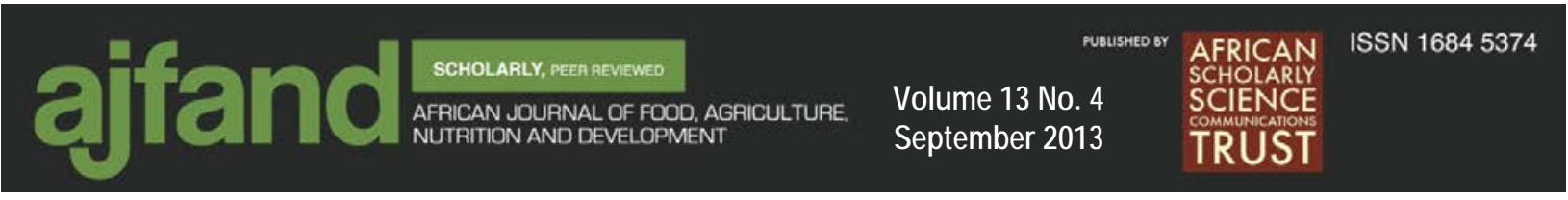

\section{REFERENCES}

1. Okon BI, Obi MB and AA Ayuk Performance of quails (Coturnix coturnix japonica) fed graded level of boiled sun-dried taro cocoyam (colocasia esculenta) as replacement for maize. Agric. J. 2007; 2: 654-657.

2. Olomu JM Monogastric Animal Nutrition: Principles and practices. Jachem Publications. Benin City, 1995.

3. Adeniyi AA and OO Balogun Utilization of flavour treated blood-rumen content mixture in the diets of laying hens. Nig. J. Anim. Prod. 2002; 29: 3439.

4. Agbede JO Characterization of the leaf meals, protein concentrates and residues from some tropical leguminous plants. J. Sci. Fd and Agric. 2006; 86: 1292-1297.

5. Emiola IA, Ologhobo AD, Akinlade J, Adedeji OS and OM Bamigbade Effects of inclusion of differently processed mucuna seed meal on performance characteristics of broilers. Trop. Anim. Prod. Invest. 2003; 6: 1321.

6. Iyayi EA Prospect and challenges of unconventional poultry feedstuffs. Nig. Poult. Sci. J. 2008; 5: 186 - 194.

7. Oboh G and AA Akindahunsi Chemical changes in cassava peels fermented with mixed culture of Aspergillus niger and two species of Lactobacillus integrated bio-system. App. Trop. Agric. 2003; 8: 63-68.

8. Aro SO, Aletor VA, Tewe OO, Fajemisin AN, Usifo B and AB Falowo Preliminary investigation on the nutrients, anti-nutrients and mineral composition of microbially fermented cassava starch residues. Proc. $33^{\text {rd }}$ Annu. Conf., $16^{\text {th }}-19^{\text {th }}$ March, 2008; 248-251.

9. Lamb GN Manual of veterinary laboratory technique. CIBA-GEIGY, Kenya 1981; 96 -107.

10. AOAC.Official Method of Analysis. Association of Officiating Analytical Chemists, Washington, D.C. 1990.

11. Vogtmann H, Pfirter $\mathbf{P}$ and AL Prabuck A new method of determining metabolisability of energy and digestibility of fatty acids in broiler diets. Brit. Poult. Sci. 1975; 16: 531. 
12. SPSS Statistical Package for Social Scientists. S.P.S.S Base 15.0 User's Guide, Copyright $\left(\right.$ 2006. S.P.S.S. Inc., 233 South Wacker Drive, $11^{\text {th }}$ Floor, Chicago, IL 60606-6412.

13 Sucharita S, Makkar HPS and K Becker Alfalfa saponins and their implications in animal nutrition. J. Agric. Food Chem. 1998; 46: 131-140.

14. Jain NC Essentials of Veterinary Hematology. Lea and Fabiger. Philadelphia, USA 1993; 1-417.

15. Guyton AC and JE Hall Textbook of Medical Physiology. $9^{\text {th }}$ Ed. W. B. Saunders Company 1996; 537-545.

16. Berg JM, Tymoczko JL and L Stryer Biochemistry. $5^{\text {th }}$ Ed. W. H. Freeman and Company. New York 2002; 519.

17. Rasper VF Chemical and physical characteristics of dietary cereal fibre. In: Inglett, G. E., Falkehag, S. I. (eds). Dietary Fibres: Chemistry and nutrition. Academy Press, New York 1979; 93-115.

18. Koseki M, Tsuji K and Y Nagaya Effects of gum Arabic and pectin on the emulsification, the lipase reaction and plasma cholesterol level in rats. Agric. Biol. Chem. 1989; 53: 3127-3132.

19. Isaksson G, Lundquist I and I Ihse Effect of dietary fibre on pancreatic enzyme activity in vitro. The importance of viscosity, $\mathrm{pH}$, ionic strength, adsorption and time of incubation. Gastroenter.1982;82: 918-924. 